\title{
ANALYSIS ACCORDING TO TIME AND FORMS OF GOALS IN THE 2016 UEFA EUROPEAN FOOTBALL FEDERATION CHAMPIONSHIP
}

\author{
Özgür Bostancı ${ }^{1}$ Abdurrahim Kaplan ${ }^{2}$ M.Hakan Mayda ${ }^{3} \quad$ Arif Satıcı $^{4} \quad$ Levent Ceylan ${ }^{5}$ Ömer Faruk \\ Yazıcı ${ }^{6}$ \\ ${ }^{12345}$ Ondokuz Mayıs University Yaşar Doğu Faculty of Sports Sciences, SAMSUN \\ ${ }^{6}$ Gaziosmanpaşa University Erbaa Vocational School
}

\begin{abstract}
The aim of this study is to analyze the time, form and how the 108 goals scored and defeated according to the outbreak of 51 games played in the 2016 UEFA European Football Championship. The data of the study were obtained from Prozone brand performance and match analysis program. In the study, the team can not qualify of the group (n:8) and qualify of the group ( $\mathrm{n}: 16$ ); the total number of goals scored, the time of goals, the formation of the goals, and the technique of the strokes used. The Independent Samples T-Test was applied to examine the difference between the groups in the SPSS 20.0 program $(p<0.05)$. According to the average of goals per game meaningfulness was observed $(p<0.001)$ there was a significant difference between the teams that qualified of the group (1.22 \pm 0.41$)$ and those who did not $(0.46 \pm 0.27)$. The time zones in the scored and conceded goals of the team qualified of the group and those who did not, significant differences were observed between groups at $0-15,30-45,45-60 \mathrm{~min}$ in scored goals $(p<0.05)$, no significant difference was found other time periods. In the competition it was determined that most goals were between 75-90 min (1.50 \pm 1.26$)$. While the significance of the goals scored from the left and the right sides among the groups was determined $(p<0.05)$, it was not found goal from the middle $(p<0.05)$.

Both in the penalty area and the penalty area outside goals, teams quaified of group were found to have more goals. According to results, in addition to increasing the tactical richness in the offensive area, the national teams and trainers must also prepare the team by analyzing the previous champions well so that the national teams can reach more goals in the championship.
\end{abstract}

Key Words: Football, Analysis, Goal.

\section{Academic Discipline And Sub-Disciplines}

Sport

\section{SUBJECT CLASSIFICATION}

Sport Science

\section{TYPE (METHOD/APPROACH)}

\author{
Sport Analysis
}

\section{INTRODUCTION}

Today, football is played by millions of people and watched by billions of people all around the world. With the development of the economy of football, which is one of the most popular sport forms played in all parts of the world, and with fast developing technology, studies to find out the success and failure states of teams have become important (Carling, 2010, Reilly and Williams, 2003). Generally, the game of football is assessed with subjective observations. Through observations, a team's good and bad sides are found and trainings are shaped in the light of the views obtained. Subjective observations can give misleading ideas because of reasons such as the conditions of viewing, human limits, bias, personal thoughts and the influence of emotions (Smith, 1996). Game analysis programs, which are necessary for objectivity, mean analysis and subjective recording of the events which occur during the game.

When considered from this point of view, analysis practices have recently become more popular among sport scientists to be able to understand different performance indicators in individual sports or team sports. A great number of analysts working in different ranks have used analysis for a great number of purposes such as technical-tactical assessment, movement analysis, providing feedback, developing norms and modeling (Shafizadeh et al, 2013, İmamoğlu et al, 2017).

In football, which is based on scoring goal and not conceding goal, there are a great number of variables influencing success. However, "goal" is the factor discriminating success from failure and it has the most effective role in assessing performance (James et al 2004, Tenga and Sigmundstad, 2011). In this case, all the factors that can result in goal should be created and while analyzing the game, all the stages that can lead to goal should be assessed, addressed as a whole and teams' performances should be analyzed accordingly. In addition, when the results which influence the score of the game in today's football are considered, teams' percentages of ball possession and playing with the ball, balls kicked to the penalty area, passes and shots to the goal post are shown among these factors. This shows the importance of shot and goal in football. In football games, approximately $80 \%$ of goals are scored as a result of consecutive 3 or more passes and 1 out of every 10 shots results in goal (Hughes and Franks, 2005, Mitrotasios and Armatas, 2014). Statistically, it 
should not be thought that a team's outclassing the opponent will be enough to win the game. However, the data obtained is an important factor that will contribute to the success of the team in future matches and to increasing the efficiency in team game (Castellano et al, 2012, Hughes and Bartlett 2002, Bakır, 2007).

However, some data such as high levels of ball possession, finding too many opportunities to score a goal, shots on target or corner are not rules which are always valid to show a good performance and to show success. A football team can win a competition or a tournament despite showing bad performance (Wright et al, 2011). The purpose of this study is to compare the formations of goals scored and conceded, the areas where goals were scored from and how the goals were scored in the matches played by the teams which could qualify out of the group and those which could not in 2016 UEFA European Cup Championship.

\section{MATERIAL AND METHOD}

This study makes an assessment of the goals scored and conceded by teams which could qualify out of the group and those which could not in a total of 51 matches in 2016 UEFA European Championship in terms of the goals' timing, formation and how they were scored. The data of the research were obtained from Prozone performance analysis program.

Statistical Analysis: In the study, the comparison of the parameters which consisted of the total number of goals scored and conceded, the formations of the goals and how they were scored by teams which could qualify out of the group $(n: 16)$ and those which could not $(n: 8)$ was conducted by using SPSS 21 program and the level of significance was taken as $p<0.05$. Independent Samples T-Test was used to check the significance between groups.

\section{RESULTS}

Total goal averages, total number of goals scored and conceded, the number of goals scored in the first half and the second half by teams which could qualify out of the group and those which could not are shown in table 1.

Table 1. Goal variables of teams who could qualify out of the group and those who could not

\begin{tabular}{|c|c|c|c|c|c|c|}
\hline Variable & Group & $\mathbf{N}$ & Ave. & S.D. & $\mathbf{t}$ & $\mathbf{P}$ \\
\hline \multirow{2}{*}{ Total Goal Average } & Qualifiers & 16 & 1.22 & 0.41 & \multirow{2}{*}{4.681} & \multirow[t]{2}{*}{0.000} \\
\hline & Non-qualifiers & 8 & 0.46 & 0.27 & & \\
\hline \multirow{2}{*}{ Number of total goals scored } & Qualifiers & 16 & 6.06 & 3.07 & \multirow{2}{*}{5.786} & \multirow{2}{*}{0.000} \\
\hline & Non-qualifiers & 8 & 1.38 & 0.74 & & \\
\hline \multirow{2}{*}{$\begin{array}{c}\text { Number of goals scored in the } \\
\text { first half }\end{array}$} & Qualifiers & 16 & 2.44 & 1.50 & \multirow{2}{*}{4.932} & \multirow{2}{*}{0.000} \\
\hline & Non-qualifiers & 8 & 0.38 & 0.52 & & \\
\hline \multirow{2}{*}{$\begin{array}{c}\text { Number of goals scored in } \\
\text { the second half }\end{array}$} & Qualifiers & 16 & 3.50 & 1.97 & \multirow{2}{*}{4.468} & \multirow{2}{*}{0.000} \\
\hline & Non-qualifiers & 8 & 1.00 & 0.76 & & \\
\hline \multirow{2}{*}{$\begin{array}{c}\text { Number of total goals } \\
\text { conceded }\end{array}$} & Qualifiers & 16 & 4.63 & 2.06 & \multirow{2}{*}{0.481} & \multirow{2}{*}{0.635} \\
\hline & Non-qualifiers & 8 & 4.25 & 1.03 & & \\
\hline \multirow{2}{*}{$\begin{array}{l}\text { Number of goals conceded } \\
\text { in the first half }\end{array}$} & Qualifiers & 16 & 1.81 & 1.47 & \multirow{2}{*}{0.305} & \multirow{2}{*}{0.763} \\
\hline & Non-qualifiers & 8 & 1.62 & 1.30 & & \\
\hline \multirow{2}{*}{$\begin{array}{c}\text { Number of goals conceded } \\
\text { in the second half }\end{array}$} & Qualifiers & 16 & 2.68 & 1.57 & \multirow{2}{*}{0.103} & \multirow{2}{*}{0.919} \\
\hline & Non-qualifiers & 8 & 2.62 & 0.91 & & \\
\hline
\end{tabular}

As can be seen from Table 1, while significant difference was found between groups in terms of total goal average, the number of total goals scored, the number of total goals scored in the first half and the number of total goals scored in the second half $(p<0.05)$; no significant difference was found between groups in terms of the number of total goals conceded, the number of total goals conceded in the first half and the number of total goals conceded in the second half $(p>0.05)$. 
Table 2. The time zones of the goals scored and conceded by the teams which qualified out of the group and those which could not.

\begin{tabular}{|c|c|c|c|c|c|c|}
\hline Variable & Group & $\mathbf{N}$ & Ave. & S.D. & $\mathbf{t}$ & $\mathbf{P}$ \\
\hline \multirow{2}{*}{$\begin{array}{l}\text { Goals scored btw min. } \\
0-15\end{array}$} & Qualifiers & 16 & 0.75 & 0.68 & \multirow{2}{*}{2.953} & \multirow{2}{*}{0.007} \\
\hline & Non-qualifiers & 8 & 0.12 & 0.35 & & \\
\hline \multirow{2}{*}{$\begin{array}{l}\text { Goals conceded btw } \\
\text { min. } 0-15\end{array}$} & Qualifiers & 16 & 0.62 & 0.72 & \multirow{2}{*}{0.873} & \multirow{2}{*}{0.392} \\
\hline & Non-qualifiers & 8 & 0.37 & 0.52 & & \\
\hline \multirow{2}{*}{$\begin{array}{c}\text { Goals scored btw min. } \\
15-30\end{array}$} & Qualifiers & 16 & 0.50 & 0.82 & \multirow[b]{2}{*}{1.567} & \multirow[b]{2}{*}{0.132} \\
\hline & Non-qualifiers & 8 & 0.12 & 0.35 & & \\
\hline \multirow{2}{*}{$\begin{array}{l}\text { Goals conceded btw } \\
\text { min. } 15-30\end{array}$} & Qualifiers & 16 & 0.37 & 0.50 & \multirow{2}{*}{0.000} & \multirow{2}{*}{1.000} \\
\hline & Non-qualifiers & 8 & 0.37 & 0.52 & & \\
\hline \multirow{2}{*}{$\begin{array}{l}\text { Goals scored btw min. } \\
\qquad 30-45\end{array}$} & Qualifiers & 16 & 1.19 & 1.17 & \multirow{2}{*}{3.347} & \multirow{2}{*}{0.003} \\
\hline & Non-qualifiers & 8 & 0.12 & 0.35 & & \\
\hline \multirow{2}{*}{$\begin{array}{l}\text { Goals conceded btw } \\
\text { min. } 30-45\end{array}$} & Qualifiers & 16 & 0.81 & 0.91 & \multirow{2}{*}{-0.147} & \multirow{2}{*}{0.885} \\
\hline & Non-qualifiers & 8 & 0.87 & 1.13 & & \\
\hline \multirow{2}{*}{$\begin{array}{l}\text { Goals scored btw min. } \\
45-60\end{array}$} & Qualifiers & 16 & 1.25 & 0.93 & \multirow[b]{2}{*}{4.258} & \multirow[b]{2}{*}{0.000} \\
\hline & Non-qualifiers & 8 & 0.12 & 0.35 & & \\
\hline \multirow{2}{*}{$\begin{array}{l}\text { Goals conceded btw } \\
\text { min. } 45-60\end{array}$} & Qualifiers & 16 & 0.87 & 1.09 & \multirow{2}{*}{0.000} & \multirow{2}{*}{1.000} \\
\hline & Non-qualifiers & 8 & 0.87 & 0.83 & & \\
\hline \multirow{2}{*}{$\begin{array}{l}\text { Goals scored btw min. } \\
60-75\end{array}$} & Qualifiers & 16 & 0.75 & 0.86 & \multirow{2}{*}{1.332} & \multirow{2}{*}{0.197} \\
\hline & Non-qualifiers & 8 & 0.37 & 0.52 & & \\
\hline \multirow{2}{*}{$\begin{array}{l}\text { Goals conceded btw } \\
\text { min. } 60-75\end{array}$} & Qualifiers & 16 & 0.69 & 1.01 & \multirow[b]{2}{*}{0.461} & \multirow[b]{2}{*}{0.650} \\
\hline & Non-qualifiers & 8 & 0.50 & 0.76 & & \\
\hline \multirow{2}{*}{$\begin{array}{l}\text { Goals scored btw min. } \\
75-90\end{array}$} & Qualifiers & 16 & 1.50 & 1.26 & \multirow[b]{2}{*}{1.978} & \multirow[b]{2}{*}{0.061} \\
\hline & Non-qualifiers & 8 & 0.50 & 0.93 & & \\
\hline Goals conceded btw & Qualifiers & 16 & 1.12 & 0.88 & & \\
\hline min. $75-90$ & Non-qualifiers & 8 & 1.25 & 0.89 & -0.326 & 0.748 \\
\hline
\end{tabular}

When the time zones of the goals scored and conceded by the teams are examined, while significant differences were found between groups in terms of the goals scored between minutes $0-15,30-45$ and $45-60$ ( $p<0.05$ ), no significant differences were found in goals scored in terms of other time zones and in terms of goals conceded in all time zones $(p>0.05)$.

Table 3 shows open play total number of goals, open play left side total number of goals, open play total number of midfield goals, open play right side total number of goals, penalty goals, goals from inside penalty box, goals from outside penalty box, goals from header, foot goals, goals from free kick, goals from free kick pass, goals from middle and long pass, set piece goals, total number of other goals, goals from opponent field, goals from own field and total number of goals with fast-attack for the teams which qualified out of the group and those which could not. 
Table 3. Some variables of teams who could qualify out of the group and those who could not

\begin{tabular}{|c|c|c|c|c|c|c|}
\hline Variable & Group & $\mathbf{N}$ & Ave. & S.D. & $t$ & p \\
\hline \multirow{2}{*}{$\begin{array}{c}\text { Total number of Open Play } \\
\text { Goals }\end{array}$} & Qualifiers & 16 & 3.31 & 2.09 & \multirow{2}{*}{5.065} & \multirow{2}{*}{0.000} \\
\hline & Non-qualifiers & 8 & 0.50 & 0.53 & & \\
\hline \multirow{2}{*}{$\begin{array}{l}\text { Total number of Goals from } \\
\text { Open Play Left Side }\end{array}$} & Qualifiers & 16 & 1.37 & 0.96 & \multirow{2}{*}{5.745} & \multirow{2}{*}{0.000} \\
\hline & Non-qualifiers & 8 & 0.00 & 0.00 & & \\
\hline \multirow{2}{*}{$\begin{array}{l}\text { Total number of Open Play } \\
\text { Goals from Midfield }\end{array}$} & Qualifiers & 16 & 0.81 & 1.17 & \multirow{2}{*}{1.681} & \multirow{2}{*}{0.107} \\
\hline & Non-qualifiers & 8 & 0.25 & 0.46 & & \\
\hline \multirow{2}{*}{$\begin{array}{l}\text { Total number of Goals from } \\
\text { Open Play Right Side }\end{array}$} & Qualifiers & 16 & 1.12 & 0.81 & \multirow{2}{*}{2.826} & \multirow{2}{*}{0.010} \\
\hline & Non-qualifiers & 8 & 0.25 & 0.46 & & \\
\hline \multirow{2}{*}{$\begin{array}{l}\text { Goals from outside the Penalty } \\
\text { Box }\end{array}$} & Qualifiers & 16 & 1.00 & 1.09 & \multirow[t]{2}{*}{3.651} & \multirow[t]{2}{*}{0.002} \\
\hline & Non-qualifiers & 8 & 0.00 & 0.00 & & \\
\hline \multirow{2}{*}{$\begin{array}{l}\text { Goals from inside the Penalty } \\
\text { Box }\end{array}$} & Qualifiers & 16 & 4.94 & 2.46 & \multirow{2}{*}{5.338} & \multirow{2}{*}{0.000} \\
\hline & Non-qualifiers & 8 & 1.25 & 0.89 & & \\
\hline \multirow{2}{*}{ Goals from Penalty } & Qualifiers & 16 & 0.31 & 0.48 & \multirow{2}{*}{-0.250} & \multirow{2}{*}{0.805} \\
\hline & Non-qualifiers & 8 & 0.37 & 0.74 & & \\
\hline \multirow{2}{*}{ Header Goals } & Qualifiers & 16 & 1.19 & 1.38 & \multirow{2}{*}{1.308} & \multirow{2}{*}{0.205} \\
\hline & Non-qualifiers & 8 & 0.50 & 0.76 & & \\
\hline \multirow{2}{*}{ Goals with foot } & Qualifiers & 16 & 4.75 & 2.11 & \multirow[b]{2}{*}{6.511} & \multirow[b]{2}{*}{0.000} \\
\hline & Non-qualifiers & 8 & 0.75 & 0.89 & & \\
\hline \multirow{2}{*}{ Free kick Goals } & Qualifiers & 16 & 0.37 & 0.72 & & \\
\hline & Non-qualifiers & 8 & 0.00 & 0.00 & 2.087 & 0.054 \\
\hline Goals from free kick nass & Qualifiers & 16 & 0.25 & 0.58 & & \\
\hline Goals Irom Iree kICK pass & Non-qualifiers & 8 & 0.12 & 0.35 & 0.559 & 0.582 \\
\hline Goals from middle and long & Qualifiers & 16 & 0.81 & 0.98 & & \\
\hline passes & Non-qualifiers & 8 & 0.00 & 0.00 & 3.313 & 0.005 \\
\hline Sot niso & Qualifiers & 16 & 1.75 & 0.93 & & \\
\hline set plece goal & Non-qualifiers & 8 & 0.50 & 0.76 & 3.284 & 0.003 \\
\hline Other goals total & Qualifiers & 16 & 0.12 & 0.50 & $-0,503$ & 0620 \\
\hline & Non-qualifiers & 8 & 0.25 & 0.71 & -0.503 & $0.0<0$ \\
\hline Total goals from opponent & Qualifiers & 16 & 0.19 & 0.54 & 1.379 & 0.188 \\
\hline midfield & Non-qualifiers & 8 & 0.00 & 0.00 & & \\
\hline & Qualifiers & 16 & 0.69 & 1.01 & 1.509 & 0.146 \\
\hline I otal goals trom own midtıeld & Non-qualifiers & 8 & 0.12 & 0.35 & & \\
\hline & Qualifiers & 16 & 0.87 & 1.15 & & \\
\hline tack goal total & Non-qualifiers & 8 & 0.12 & 0.35 & 1.789 & 0.087 \\
\hline
\end{tabular}

When Table 3 is examined, it can be seen that while there were significant differences between open play total number of goals, open play left side total number of goals, open play right side total number of goals, goal from inside penalty box, goal from outside penalty box, total number of foot goals, total number of goals from middle and long passes and total number of set piece goals $(p<0.05)$, no significant difference was found between groups in terms of open play total 
number of cross goals, penalty goals, goals from header, goals from free kick, goals from free kick pass, total number of other goals, goals from opponent field, goals from own field and total number of goals with fast-attack ( $p>0.05)$.

\section{DISCUSSION}

When the goal analyses of the teams which qualified out of the group and those which could not in UEFA 2016 European Championship were examined, while significant difference was found between the total goal averages of the teams which qualified in terms of goals scored both in the first half and the second half $(p<0.05)$, no significant difference was found between groups in the number of total goals conceded although the average goals conceded were higher in both halves in the teams which qualified out of the group ( $p>0.05$ ).

It was found that the percentages of the goals scored and conceded in both the first half and the second half were higher in the teams which qualified out of the group when compared with those which could not. Goals scored have a key role in teams' success and for a good analysis both in sport games and in major tournament organizations (Michailidis et al, 2013). Of the 108 goals scored in 51 matches played in the tournament, 64 (59\%) were scored in the second half. In their study, Armatas et al, (2007) found that most of the goals scored in 1998, 2002 and 2006 FIFA World Cup were scored in the second half. In their study, Alberti et al, (2013) found that the goals scored in the second half (55.1\%) were higher than the goals scored in the first half (44.9\%). In addition, it was reported that the goals scored in UEFA Champions league 2004-2005, 2005-2006, 2006-2007 seasons were mostly scored in the second half (Sönmeyenmakas, 2008). In another study which analyzed the goals scored in the quarter finals, semi finals and finals of 2000 European Football Championship, it was found that more goals were scored in the second half (Egesoy et al, 2001). The studies in literature have similar results to the results of our study.

In the study Işık et al, (2000) conducted, 24 (28.9\%) of the goals in 2000 European Football Championship were between minutes 46 and 60 . In another study, it was reported that $27 \%$ of the goals scored in 1996 European Football Championship were between minutes 76 and 90 (Işık 1996). In their study, Armatas et al, (2007) found that most of the goals scored were scored in the last 15 minute period (75-90+) in 3 World Cups $(1998,2002,2006)$. Njororal (2013) found that the highest number of goals scored in 2010 World Cup were scored in minutes between 31-45 and 76-90.

In addition, when the goal timing of the matches in the finals of last four years' Champion Leagues were examined in terms of the teams which won and which lost, although no statistically significant difference was found, it was found that the time zones when the highest number of goals scored by the teams which won were $90+$ with $50 \%$ and between minutes 1 and 15 with 20\% (Çoban et al, 2016). Doğan et al, (2004) found in their study which analyzed the goals scored in Turkey Super League that the highest number of goals scored were between minutes 76 and 90 . It can be said that the reason why the goals scored and conceded were mostly within the last 15 minutes (between minutes 75 and 90 ) were physical fatigue of the players, increases in the rate of mistakes and of course tactical changes to win the match. Of the 76 goals scored in open play in 2016 UEFA European Cup Championship, 57 were scored with preparation passes in the open play. While significance was found in the number of total goals scored from the left and right side $(p<0.05)$, no difference was found in the total number of goals from the midfield $(p>0.05)$. In a study conducted to analyze the goals scored in 2010 World Cup in South Africa, it was found that $71.4 \%$ of the goals scored were from open play (Njorroral 2013). It was found that the highest number of goals with passes formed in open play $(22.39 \%)$ were scored with attacks from the left side, while the second highest number (20.20\%) were scored with attacks from the right side. In 2006 FIFA World Cup, $40 \%$ of the goals were scored from the left side, $34.2 \%$ were scored from the midfield and $25.8 \%$ were scored with passes from the right side. In a study on the effects of collective performance of 2010 World Champion Spain team on winning the matches, it was found that the attacks were mostly on the left side (Erdil et al, 2013). As can be understood from the studies conducted, it can be concluded that the reason why more goals are scored from this side is the passes on target by left wing players, the talent of the players and the weak defense of the opponent team players on the right (Erdil et al, 2013). In addition, unlike these studies, there are also some studies which show that in matches in major organizations, the attacks resulting in goal evolve in the midfield. It was found that the attacks resulting in goal in UEFA Champions League in 2004-2005 (80\%), 2005-2006 (82.6\%), and 2006-2007 (76.7\%) seasons mostly evolved in the center (Sönmeyenmakas, 2008). It was recorded that $40.11 \%$ (140) of the 349 goals scored in 2012 FIFA World Futsal Cup were from the midfield (Göral and Saygın, 2011).

Significant difference was found between groups in the total number of goals from inside the penalty box and those from outside the penalty box in 2016 UEFA European Cup Championship. In goals scored both from inside and outside the penalty box, it was found that the teams which qualified out of the group had higher rates of goal. While the total number of goals from inside the penalty box was $89(84.8 \%)$, the total number of goals from outside the penalty box was 16 $(15.2 \%)$. We can say that in the tournament, the teams which could not qualify out of the group could not score goals from outside the penalty box and that this has an influence on teams' success. In the analysis of goals scored in 2000 European Cup Championship, it was found that $81.1 \%$ (68 goals) were scored from inside the penalty box, while $18.9 \%$ (15 goals) were scored from outside the penalty box (Işık et al, 2000). It was found that the goals scored in UEFA Champions League 2004-2005 (76.4\%), 2005-2006 (77.5\%) and 2006-2007 (77\%) season matches were mostly from inside the penalty box (Sönmeyemakas, 2008). In another study which was on the analysis of goals scored in Turkey Football League, it was found that $85.5 \%$ of the goals scored in first league were from the penalty area (Eniseler and Egesoy, 1995). The reason why footballers prefer goal shots from places close to the goalpost is the fact that the hit rate is high and shots from close cause a disadvantage to goal keepers (Çakıroğlu et al, 2002).

When the analyses of 2016 UEFA Europe Cup Championship are reviewed, it can be seen that 32 of the 108 goals are goals scored from outside the open play. $13(41 \%)$ of these were scored with long passes, $6(19 \%)$ were scored from free

2486 | P a g e

De be mber 2017

https://cirworld.com 
kick, $5(16 \%)$ were scored with pass from free kick and $8(25 \%)$ were scored from penalty. No significance was found between groups in the goals scored within this set. It was found that the teams which could not qualify out of the group scored more goals from penalty. It was reported that of the 147 goals scored in 2006 FIFA World Football Cup, 24 (16\%) were scored from free kick, $13(9 \%)$ were scored from penalty, $12(8 \%)$ were scored from corner and $6(4 \%)$ were scored from throw-in (Acar et al, 2007). It was found that in UEFA Champions League 2004-2005 (84\%), 2005-2006 (78.6\%) and 2006-2007 (79.9\%) seasons, higher number of goals were scored with foot (Sönmeyenmakas, 2008). In a similar study, it was found that $77.1 \%$ of the goals scored in Turkey were scored with foot, while $22.9 \%$ were scored from header (Enisler and Egesoy, 1995). In a study conducted by Çoban et al, (2016) which was on set piece and goal analysis of the last four years' Champions League final matches, it was found that in the goal hit techniques of the winning and losing teams, $80 \%$ of the goals were hit with foot, while $20 \%$ were headers. In addition, it was reported that $70 \%$ of the goals scored by winning teams were scored with only one touch to the last hit, while the teams which lost scored their goals mostly with foot and with one touch.

In another study, Çoban et al, (2016) found that there was no significant difference between winning and losing teams in terms of set piece timing, set piece type, set piece hit and the area of hit and 2 of 61 set piece organizations resulted in goal (Çoban et al, 2016).

When the goal formation of the teams which qualified out of the group and those which could not in UEFA 2016 Europe Championship were examined, a significant difference was found between groups in terms of goals from the opponent midfield, goals from own midfield, and goals from fast attacks. However, $12(80 \%)$ of these 15 goals from fast attacks were from the attacks in the team's own midfield, $3(20 \%)$ were from the attacks in the opponent team's midfield. Only 1 of these 15 goals was from the teams which could not qualify out of the group.

Sönmeyenmakas (2008) found that in UEFA Champions League 2004-2005, 2005-2006, 2006-2007 seasons, the highest number of attacks which resulted in goal occurred with fast attacks. In another study, it was found that $70 \%$ of the goals scored by teams which won in final matches in the last four Champions League final matches were started with balls possessed in the opponent's midfield and there was a significant difference between the total number of goals scored from the team's own midfield and the opponent's midfield (Çoban et al, 2016).

\section{REFERENCES}

1. Acar, M. F., Yapıcıoğlu, B., Arıkan, N., Yalçın, S., Ateş, N., \& Ergün, M. (2007). Analysis of goals scored in 2006 world cup. VI. World Congress on Science and Football, Book of Abstracts, January, 15-20.

2. Alberti, G., laia, F. M., Arcelli, E., Cavaggioni, L., \& Rampinini, E. (2013). Goal scoring patterns in major European soccer leagues. Sport Sciences for Health, 9(3), 151-153.

3. Armatas, V., Yiannakos, A., \& Sileloglou, P. (2007). Relationship between time and goal scoring in soccer games: Analysis of three World Cups. International Journal of Performance Analysis in Sport, 7(2), 48-58.

4. Bakır, İ. (2007). Technical analysis of 2006 word cup soccerchampionıtaly. VI.WordCongress on Scienceand Football. Book of Abstracts, January, 15-20.

5. Carling, C. (2010). Analysis of physical activity profiles when running with the ball in a professional soccer team. Journal of Sports Sciences, 28(3), 319-326.

6. Castellano, J., Casamichana, D., \& Lago, C. (2012). The use of match statistics that discriminate between successful and unsuccessful soccer teams. Journal of human kinetics, 31, 137-147.

7. Çakıroğlu, M., Işık, O., Kızılet, A., \& Şuta, C. (2002). "2002 FIFA Dünya kupasının teknik analizi”, 7. Uluslararası Spor Bilimleri Kongresi, s.224.

8. Çoban, O., Taşkın, AK., Marangoz, İ., \& Akgül, F. (2016). Son dört yılın şampiyonlar ligi final maçlarının duran top ve gol analizi. The Journal of Academic Social Science, 4(36), 719-726.

9. Doğan, M., Doğan, A., \& Alkan, A. (2017). 2001-2002 Futbol Sezonunda Türkiye 1. Süper Liginde Atılan Gollerin Incelenmesi/The Study Of Goals Scored In Turkısh Super League In 2001-2002 Football Season

10. Egesoy, H., Bizati, O., Şenkibar, B., \& Tavlı, H. (2001). Avrupa Futbol Şampiyonası Çeyrek Final, Yarı Final ve Final Maçlarında Kaydedilen Gollerin Analizi. 2. Futbol ve Bilim Kongresi, 16-18 Ekim, p-28, İzmir.

11. Eniseler, N., \& Egesoy, H. (1995). Analysis of Goals Scored by the Teams in the Turkish Professional Soccer Leagues and Comparing them According to League Levels. Dept. Of Physical Education, Celal Bayar University, Turkey.

12. Erdil, G., Bozkurt, S., İşleğen, Ç., \& Ölçücü, B. (2013). 2010 Futbol Dünya Kupasında İspanya Takımının Kollektif Performansının Maçların Kazanılmasında Etkisi. Spor ve Performans Araştırmaları Dergisi, 4(2). 
13. Göral, K., \& Saygın, Ö. (2011). 2012 Fıfa Futsal Dünya Kupasının Analizi. Cbü Beden Eğitimi Ve Spor Bilimleri Dergisi, 6(1), 28-35.

14. Hughes, M. D., \& Bartlett, R. M. (2002). Performance analysis. Journal of sports sciences, 20(10), 735-737.

15. Hughes, M., \& Franks, I. (2005). Analysis of passing sequences, shots and goals in soccer. Journal of sports sciences, 23(5), 509-514.

16. Işık, O. (1999). 1996 Avrupa Futbol Şampiyonası gol analizleri ve Türk milli takımının ikili mücadele-pas analizleri. Trakya Üniversitesi, Sağıık Bilimleri Enstitüsü, Beden Eğitimi ve Spor Anabilim Dalı, Yüksek Lisans Tezi, Edirne.

17. Işık, O., Toksöz, I., \& Çakıroğlu, M. (2001). Avrupa Futbol Şampiyonası Gollerin Analizleri. 2. Futbol ve Bilim Kongresi, 16-18 Ekim 2001, p-27, İzmir.

18. İmamoğlu, O., Erkin, A., Mayda, M. H., Öztürk, O., \& Yılmaz, A. K. (2017). 12th World Universities Wrestling Championship Free Style Competition Technical Analysis. European Journal of Physical Education and Sport Science.

19. Jinshan, X., Xiaoke, C., Yamanaka, K., \& Matsumoto, M. (1993). Analysis of the goals in the 14th World Cup. Science and football II, 203-205.

20. Jones, P. D., James, N., \& Mellalieu, S. D. (2004). Possession as a performance indicator in soccer. International Journal of Performance Analysis in Sport, 4(1), 98-102.

21. Michailidis, Y., Michailidis, C., \& Primpa, E. (2013). Analysis of goals scored in European Championship 2012.

22. Mitrotasios, M., \& Armatas, V. (2014). Analysis of goal scoring patterns in the 2012 European Football Championship. United States Sports Academy.

23. Njororai, W. W. S. (2013). Analysis of goals scored in the 2010 world cup soccer tournament held in South Africa. Journal of Physical Education and Sport, 13(1), 6.

24. Reilly, T. (2003). Science and soccer. Routledge.

25. Shafizadeh, M., Taylor, M., \& Peñas, C. L. (2013). Performance consistency of international soccer teams in Euro 2012: A time series analysis. Journal of human kinetics, 38, 213-226.

26. Sönmeyenmakas, A. (2008). UEFA şampiyonlar liginde atılan gollerin analizi.

27. Tenga, A., \& Sigmundstad, E. (2011). Characteristics of goal-scoring possessions in open play: Comparing the top, in-between and bottom teams from professional soccer league. International Journal of Performance Analysis in Sport, 11(3), 545-552.

28. Wright, C., Atkins, S., Polman, R., Jones, B., \& Sargeson, L. (2011). Factors associated with goals and goal scoring opportunities in professional soccer. International Journal of Performance Analysis in Sport, 11(3), 438449 . 